УДК 619:616.995.132:636.4

(C) 2016

Манойло Ю. Б., аспірант

(науковий керівник - доктор ветеринарних наук, професор В. О. Свстаф'єва)

Полтавська державна аграрна академія

\title{
ЕФЕКТИВНІСТЬ СУЧАСНИХ ПРЕПАРАТІВ ЗА СПОНТАННОГО ЕЗОФАГОСТОМОЗУ СВИНЕЙ
}

Рецензент - доктор ветеринарних наук I. І. Панікар

У статті представлені результати наукових досліджень щодо вивчення ефективності сучасних препаратів за спонтанного езофагостомозу свиней, які дають змогу підвищити екстенсефективність та інтенсефективність антигельмінтиків за допомогою пробіотиків та пребіотиків. Встановлено, щуо застосування кормових добавок у поєднанні з протипаразитарним засобом підвишує терапевтичну ефективність «Бровермектину» $2 \%$ водорозчиного за езофагостомозної інвазії свиней. Доведено, щзо ферментнопробіотичні препарати сприяють збільшенню середньодобових приростів маси тіла та впливають на збереженість поросят.

Ключові слова: свині, езофагостомоз, ефективність, протипаразитарний препарат, пробіотик, пребіотик.

Постановка проблеми. Упродовж останніх років у багатьох країнах світу накопичено значний досвід застосування у практиці ветеринарної медицини різноманітних протипаразитарних лікувальних засобів, які відносяться до різних класів сполук і використовуються для лікування гельмінтозів свиней, зокрема езофагостомозу.

У структурі реалізації антигельмінтиків найбільшим попитом користуються препарати групи макроциклічних лактонів $(51,6 \%)[1,2,12]$.

Гельмінти негативно впливають на нормальну мікрофлору організму хазяїна, викликаючи дисбактеріоз, який ускладнює перебіг паразитарного захворювання і нерідко обумовлює тривалу дисфункцію кишечника.

Одним із факторів, здатних активізувати вплив умовно-патогенних мікробів на організм тварин, є нематоди, зокрема збудник езофагостомозу [3].

На сьогодні використання кормових добавок iз застосуванням пробіотиків та пребіотиків $\epsilon$ найбільш ефективним засобом для лікування $\mathrm{i}$ профілактики хвороб шлунково-кишкового тракту свиней, а дослідження ефективності сучасних препаратів у разі езофагостомозу за допомогою кормових добавок $є$ перспективним напрямом наукових досліджень.

Аналіз останніх досліджень і публікацій, у яких започатковано розв'язання проблеми. Езофагостомоз свиней - гельмінтозне захворювання, що викликається паразитуванням в кишечнику нематод роду Oesophagostomum, i характеризується вузликовим ураженням товстого відділу кишечника. Клінічно хвороба проявляється проносом, зниженням апетиту, схудненням тварин $[10,11]$.

За даними науковців [5, 9], мікрофлора тонкого і товстого кишечника у поросят до 5-6місячного віку стабілізується. Вона представлена облігатною (лактобацили, біфідобактерії, бактероїди, непатогенні кокові форми) і факультативною (умовно-патогенні стафілококи, стрептококи, патогенні серогрупи E. coli, клостридіiі, протей, гриби) мікрофлорою. Облігатна мікрофлора кишечника свиней становить 94-95,2 \%, факультативна $-6-4,8 \%$. Доведено, що у період паразитування езофагостом у товстому кишечнику поросят формується мікропаразитоценоз, переважаючими співчленами якого $є$ токсиноутворюючі стафілококи, гемолітичні стрептококи, патогенні серогрупи E. coli, клостридіï, протей, гельмінти і гриби. Зазначені зміни складу мікрофлори кишечника характерні для дисбактеріозу $[6,8]$.

Останнім часом науковці з метою нормалізації мікрофлори дегельмінтізованих тварин рекомендують використовувати пробіотичні препарати, що дає можливість усунути явища дисбактеріозу, який виникає за рахунок використання антигельмінтиків, і сприяє якнайшвидшій нормалізації мікрофлори кишечника і його функціональної діяльності $[4,7]$.

На підставі вищевикладеного можна зробити висновок, що комплексний підхід до проблеми езофагостомозу і спричиненого ним дисбактеріозу дає можливість більш успішно проводити заходи, спрямовані не тільки на ліквідацію інвазії, а й на нормалізацію мікрофлори кишечника хворих тварин. 
Мета досліджень - визначити ефективність сучасних препаратів за езофагостомозу свиней.

Основним завданням було встановлення ефективності «Бровермектину» $2 \%$ водорозчинного та у поєднанні його 3 пробітиком і пребіотиком за спонтанного езофагостомозу свиней.

Матеріали і методи досліджень. Дослідження проводили впродовж 2015-2016 рр. на базі наукової лабораторії кафедри паразитології та ветеринарно-санітарної експертизи факультету ветеринарної медицини Полтавської державної аграрної академії. Експериментальні досліди виконували в умовах ТОВ «Октан» Зіньківського району Полтавської області на супоросних свиноматках української білої породи, спонтанно інвазованих езофагостомами за інвазії середньої

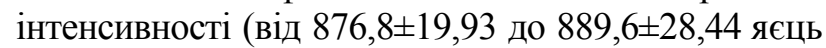
у 1 г фекалій). Гельмінтоовоскопію проб фекалій проводили за методом В. Н. Трача.

Були сформовані три дослідні і дві контрольні (хворі та клінічно здорові) групи по п'ять голів у кожній. Препарати задавали за місяць до опоросу.

Свиням першої дослідної групи випоювали груповим способом «Бровермектин» $2 \%$ водорозчинний у дозі 1 мл/50 кг маси тіла одноразово. Розраховану для всього поголів'я дозу препарату розводили в одній третині добової норми питної води та випоювали упродовж однієї доби.

Свиням другої дослідної групи випоювали груповим способом «Бровермектин» $2 \%$ водорозчинний у дозі 1 мл/50 кг маси тіла одноразово та одночасно застосовували пробіотик «Емпробіо», який задавали разом з питною водою у дозі 40 мл на голову 15 діб поспіль.

Свиням третьої дослідної групи випоювали груповим способом «Бровермектин» $2 \%$ водорозчинний у дозі 1 мл/50 кг маси тіла одноразово та одночасно застосовували ферментно- пробіотичний препарат «Вітацелл-Ф», який задавали разом 3 комбікормом у дозі 1 кг/т корму 30 діб поспіль.

Свиней контрольних груп не дегельмінтизували. Ефективність антигельмінтиків визначали на 3, 7 та 14 добу після застосування препаратів за показниками екстенсивності та інтенсивності інвазії (EI, II). До та на 30 добу після опоросу свиноматок дослідних та контрольних груп визначали: кількість поросят за опоросу, масу тіла, середньодобові прирости та збереженість поросят. Головними показниками дії препаратів були екстенсефективність (ЕЕ) та інтенсефективність (IE).

Статистичну обробку результатів експериментальних досліджень проводили шляхом визначення середнього арифметичного (М) та його похибки (m).

Результати досліджень. За результатами проведених досліджень встановлено, що терапевтична ефективність «Бровермектину» 2 \% водорозчинного за езофагостомозу свиней становила $100 \%$ (див. табл.).

Разом із тим, найшвидше одужання свиноматок встановлювали в групі тварин, яким разом із «Бровермектином» $2 \%$ водорозчинним задавали кормову добавку «Вітацелл-Ф». Так, на 3-тю добу досліду ЕЕ та IЕ дорівнювали відповідно 80 та 99,52\%, на 7-му добу - $100 \%$.

Застосування «Бровермектину» $2 \%$ водорозчинного у поєднанні 3 пробіотиком «Емпробіо» також призводило до швидшого одужання, ніж застосування тільки протипаразитарного засобу i одночасно більш тривалого, ніж у випадку застосування «Бровермектину» $2 \%$ у поєднанні із «Вітацеллом-Ф». Так, ЕЕ та ІЕ дорівнювали відповідно: на 3-тю добу - 80 та 98,11 \%, на 7-му 80 та $99,53 \%$, на $14-$ ту $-100 \%$.

Терапевтична ефективність комплексного застосування протипаразитарного засобу 3 ферментно-пробіотичними препаратами за езофагостомозу свиней (n=5)

\begin{tabular}{|c|c|c|c|c|}
\hline \multirow{2}{*}{$\begin{array}{c}\text { Препарат, } \\
\text { групи свиней }\end{array}$} & $\begin{array}{c}\text { Показники } \\
\text { ефективності, } \\
\text { \% }\end{array}$ & \multicolumn{3}{|c|}{ Після обробки, доба } \\
\cline { 3 - 5 } & $\mathrm{EE}$ & 3 -тя & 7 -ма & 14-та \\
\hline $\begin{array}{c}\text { «Бровермектин» } \\
\text { \% водорозчинний, № 1 }\end{array}$ & $\mathrm{IE}$ & 97,72 & 99,18 & 100 \\
\hline $\begin{array}{c}\text { «Бровермектин» } \\
\text { \% водорозчинний, } \\
\text { «Емпробіо», № 2 }\end{array}$ & $\mathrm{EE}$ & 80 & 80 & 100 \\
\cline { 2 - 5 } & $\mathrm{IE}$ & 98,11 & 99,53 & 100 \\
\hline $\begin{array}{c}\text { «Бровермектин» } \\
\text { \% водорозчинний, } \\
\text { «Вітацелл-Ф», № 3 }\end{array}$ & $\mathrm{EE}$ & 80 & 100 & 100 \\
\cline { 2 - 5 } & $\mathrm{IE}$ & 99,52 & 100 & 100 \\
\hline
\end{tabular}




\section{СТОРІНКА МОЛОДОГО ВЧЕНОГО}

Застосування «Бровермектину» 2 \% водорозчинного хворим на езофагостомоз свиноматкам призводило до їх одужання тільки на 14-ту добу експерименту. Так, ЕE та IE дорівнювали відповідно: на 3-тю добу - 80 та 97,72 \%, на 7-му - 80 та $99,18 \%$, на 14 -ту $-100 \%$.

Одночасно встановлено, що ферментнопробіотичні препарати за одночасного застосування із протипаразитарним засобом сприяють збільшенню середньодобових приростів маси тіла та впливають на збереженість поросят, які отримані від пролікованих свиноматок.

\section{БІБЛІОГРАФІЯ}

1. Антигельмінтні препарати на фармацевтичному ринку України / [Косенко М., Гуфрій Д., Юськів І. та ін.] // Ветеринарна медицина України. - 1998. - №3. - С. 34-36.

2. Бісюк Ш. Ю. Каталог ветеринарних лікарських засобів і кормових добавок для тварин, зареєстрованих і дозволених для використання в Україні / Ш. Ю. Бісюк. - К. : Освіта, 2006. - 170 с.

3. Микрофлора кишечника свиней при гельминтозах / [Гудкова А. Ю., Молева А. А., Иванюк В. П., Трофимова Е. Г.] // Теория и практика борьбы с паразитарными болезнями : матер. докладов научной конференции. - М., 2004. Вып. 5. - С. 135-137.

4. Домосканов И. С. Повышение прироста массы свиней и экстенсэффективности антигельминтиков при микстнематодозах с помощью пробиотиков / И. С. Домосканов // Русский паразитологический журнал. - М., 2012. - №1. - С. 110-113.

5. Ленцнер A. A. Лактофлора животного организма и её защитная функция / А. А. Ленцнер // Теоретические и практические проблемы гнотобиологии. - М. : Агропромиздат, 1986. - С. 195.

6. Матусявичус А. П. Патоморфологические изменения и состав микрофлоры в кишечнике поросят, заражённых аскаридами и эзофагостомумами / А. П. Матусявичус, К. А. Шимкус // Acta parasitologia Lituanica. - 1983. - Vol. 20. C. 100-104.

\section{Висновки:}

1. «Бровермектин» $2 \%$ водорозчинний $\epsilon$ ефективним лікарським засобом (EE, IE - 100 \%) за езофагостомозу свиней.

2. Комплексне застосування антигельмінтика i ферментно-пробіотичних препаратів підвищує ефективність дегельмінтизації за езофагостомозу свиней.

Перспективами подальших досліджень є вивчення економічної ефективності комплексного застосування антигельмінтика i ферментнопробіотичних препаратів за езофагостомозу свиней.

7. Молева А. А. Динамика формирования микропаразитоценозов при нематодозах свиней и коррекция ее антгельминтиками и пробиотиками : автореф. дисс. на соиск. уч. степени к. вет. н. : спец. 03.00.19 «Паразитология», 16.00.03 «Ветеринарная микробиология, вирусология, эпизоотология, микология с микотоксикологией и иммунология» / А. А. Молева. - Иваново, 2004. - 19 с.

8. Микрофлора кишечника свиней при эзофагостомозе / [Молева А. А., Иванюк В. П., Гудкова А. Ю., Трофимова Е. Г.] // Актуальные проблемы науки в агропромышленном комплексе : матер. 55-ой Междунар. науч.-практ. конф. - Кострома, 2004. - Т. 2. - С. 132-133.

9. Ноздрин Н. T. Выращивание молодняка свиней / Н. Т. Ноздрин, А. Ф. Сагло. - М. : Агропромиздат, 1990. $-143 \mathrm{c}$.

10. Патологическая диагностика болезней свиней / [Авроров А. А., Акулов А. В., Бубра Л. Г. и др.] ; под. ред. В. П. Шишкова. - М. : Колос, 1984. - $335 \mathrm{c}$.

11. Шендрик Л. I. Паразитарні хвороби тварин: діагностика, профілактика, лікування : навч. посібник / Л. І. Шендрик, Х. М. Шендрик. Дніпропетровськ : «Свідлер А. Л.», 2011. - 212 с.

12. Ferguson $D$. L. Ivomec for swine parasite control / D. L. Ferguson, A. Hogg // Ecextension circular Nebraska cooperative extension service. Nebraska agr. res. Div. - 1987. - T. 87/219. P. 29-31. 